\title{
Effects of Long Term Exposure to Aspirin on Growth, Functionality and Protein Profile of Lactobacillus rhamnosus (LGG) (ATCC 53103)
}

\author{
Temitayo Obanla ${ }^{1}$, Sarah Adjei-Fremah ${ }^{2}$, Rabin Gyawali ${ }^{1}$, Tahl Zimmerman ${ }^{1}$, Mulumebet Worku ${ }^{2} \&$ \\ Salam A. Ibrahim ${ }^{1}$ \\ ${ }^{1}$ Food Microbiology and Biotechnology Laboratory, North Carolina A\&T University, Greensboro, NC, USA \\ ${ }^{2}$ Department of Animal Sciences, North Carolina A\&T University, Greensboro, NC, USA \\ Correspondence: Salam A. Ibrahim, Food Microbiology and Biotechnology Laboratory, 173 Carver Hall, \\ Greensboro, North Carolina. Tel: 336-285-4860. Fax: 336-334-7239. E-mail: ibrah001@ncat.edu
}

Received: April 25, 2016 Accepted: June 2, 2016 Online Published: June 27, 2016

doi:10.5539/jfr.v5n4p46 URL: http://dx.doi.org/10.5539/jfr.v5n4p46

\begin{abstract}
In the present study, we determined the effects of long-term exposure to aspirin on the growth and functionality of Lactobacillus rhamnosus. One isolated colony of L. rhamnosus was propagated three times in deMan, Rogosa and Sharpe (MRS) broth and incubated at $37^{\circ} \mathrm{C}$. The active strain was then harvested and washed with $0.1 \%$ peptone water. Cells were transferred into $9 \mathrm{~mL}$ MRS broth containing approximately $6 \mathrm{mg} / \mathrm{mL}$ of aspirin, vigorously mixed and incubated for $4 \mathrm{~h}$. The cells were further harvested, transferred into MRS broth and incubated at $37^{\circ} \mathrm{C}$. The exposure protocol was repeated for five sequential transfers a week, and the exposed strain cell was surface plated onto MRS agar containing equal amount of aspirin. One isolated colony of aspirin exposed L. rhamnosus from an aspirin containing agar plate was further activated in MRS broth. This procedure was repeated sequentially for 12 consecutive weeks. Bacterial populations, $\beta$-galactosidase activity ( $\beta$-gal), and protein expression were determined. Bacterial cells unexposed to aspirin were used as the control. Our results showed that $L$. rhamnosus could survive after long term exposure to a sub-inhibitory concentration of aspirin. The average $\beta$-gal activity of $L$. rhamnosus in unexposed cells was $153 \pm 2.5 \mathrm{Gal} \mathrm{U}$.; however, $\beta$-gal activity was completely inhibited in exposed cells throughout the exposure period. There was approximately $54 \%$ more protein expressed in the long term aspirin-exposed strain compared to the short term exposed $(4 \mathrm{~h})$ strain as determined by BCA assay. In addition, the SDS-page gel indicated the synthesis of more protein in the exposed $L$. rhamnosus. The onset of common or chronic illnesses, especially among the elderly population, is often treated with common medications. However, regular the intake of medical drugs such as aspirin could affect beneficial gut microflora. Therefore, foods containing probiotics such as yogurt and other functional foods are important for the maintenance of optimal gastrointestinal health.
\end{abstract}

Keywords: L. rhamnosus, mutation, $\beta$-gal, probiotics, gut flora, drug interaction, long term exposure

\section{Introduction}

Aspirin (acetylsalicylic acid) is among the most popular therapeutic non-steroidal anti-inflammatory drugs (NSAID). Aspirin is commonly used as an analgesic to relieve minor aches and pains, as an antipyretic to reduce fever, and as an anti-inflammatory for conditions such as arthritis (Zhou, Boudreau, \& Freedman, 2014). Studies suggest that regular use of aspirin, long-term or short term, might not only reduce cancer incidence and death, but also decrease the risk of distant metastasis among cancer survivors (Zhou et al., 2014). Although aspirin confers a number of benefits, the well-recognized side effect profile of NSAIDs and, in particular, the risk of peptic ulceration and hemorrhagic stroke, is a major drawback to their routine use (Huang, Strate, Ho, Lee, \& Chan, 2010). Upper gastrointestinal (GI) bleeding is perhaps the most severe complication associated with regular aspirin consumption. This common side effect of long-term aspirin use is thought to occur via aspirin's inhibition of the COX-1 enzyme. The effect of such inhibition is a reduction in pain which thereby reduces the synthesis of prostaglandins which protect the gastric mucosa from acid-induced damage. Bacteria living within the intestinal lumen are known to play an important role in host homoeostasis. Aspirin and related compounds have a variety of effects on microorganisms, and gut bacteria have been shown to play a role in NSAID induced intestinal injury (Upreti, Kannan, \& Pant, 2010). An in-vitro study by Obanla and Ibrahim (2015) suggested that aspirin could alter the functionality and reduce the growth of beneficial bacteria such as Lactobacillus and 
bifidobacteria cells. Cederlund and Mardh (1993) reported that aspirin and other NSAIDs interfere with the growth of both Gram-negative and Gram-positive bacteria in vitro, such as Escherichia coli, Candida albicans, Staphylococcus saprophyticus, Pseudomonas cepacia, and Staphylococcus aureus. Most of these studies have revealed the short term side effects of aspirin, but some individuals ingest aspirin dosages ranging from between $75 \mathrm{mg}$ and $325 \mathrm{mg}$ on a long-term basis. Long term usage of aspirin is defined as the intake of at least 3 tablets a week for 3-60 months (Huang, Strate, Ho, Lee, \& Chan, 2011). However, studies on the effects of long term aspirin exposure on intestinal bacteria are inadequate in the available literature. Consequently, the present study was undertaken to determine the effect of long term aspirin exposure on growth and functionality of Lactobacillus rhamnosus.

\section{Materials and Methods}

\subsection{Culture Activation and Preparation}

L. rhamnosus (LGG) (ATCC 53103) was obtained from the culture collection of the Food Microbiology and Biotechnology Laboratory at North Carolina A\&T State University. The strain was activated by transferring 100 $\mu \mathrm{l}$ of stock culture into $5 \mathrm{~mL}$ deMan, Rogosa and Sharpe (MRS) broth (Neogen, Lansing, MI) and incubated at $37{ }^{\circ} \mathrm{C}$ for $18 \mathrm{~h}$. Bacterial cultures were streaked onto MRS agar and further incubated at $37{ }^{\circ} \mathrm{C}$ for $48 \mathrm{~h}$. One isolated colony of L. rhamnosus was then propagated three times in MRS broth at $37^{\circ} \mathrm{C}$ overnight for the drug treatment assay.

\subsection{Chemicals}

All chemicals and reagents were purchased from Sigma-Aldrich Co. (St. Louis, MO, USA) and Thermo Fisher Scientific Co. (Madison, WI, USA).

\subsection{Aspirin Assay Procedure}

One isolated colony of L. rhamnosus was propagated three times in MRS broth and incubated at $37^{\circ} \mathrm{C}$ until the stationary phase was reached. When the active strain with an optical density of approximately 0.9 (O.D. $610 \mathrm{~nm}$ ), it was then harvested by centrifugation at $7800 \times \mathrm{g}$ and $4{ }^{\circ} \mathrm{C}$ for $10 \mathrm{~min}$ (Sorvall $\mathrm{RC} 6$ Plus Centrifuge, Thermo Scientific Co., Asheville, NC, USA). The pellet was washed with sterilized $0.1 \%$ peptone water (Bacto peptone, Becton Dickinson, Sparks, MD, USA). Cells were transferred into $9 \mathrm{ml}$ MRS broth containing approximately 6 $\mathrm{mg} / \mathrm{mL}$ aspirin, vigorously mixed and incubated for $4 \mathrm{~h}$ at $37^{\circ} \mathrm{C}$. The concentration was selected by taking into consideration the minimum inhibitory concentration (MIC) of the aspirin (Obanla \& Ibrahim, 2015). The MIC is the lowest concentration of an antimicrobial that inhibits the visible growth of a microorganism during a $16 \mathrm{~h}$ incubation period. The aspirin-exposed cells were further harvested, transferred into MRS broth, and incubated at $37^{\circ} \mathrm{C}$ until an optical density reading of 0.9 was reached. The exposure protocol was repeated for five sequential transfers within a week, and the exposed cell was then surface plated onto MRS agar containing equal amounts of aspirin. One isolated colony of aspirin-exposed L. rhamnosus from an aspirin containing agar plate was further activated in MRS broth and further treated with an equal concentration of aspirin. This procedure was repeated sequentially for 12 consecutive weeks. Bacterial populations and $\beta$-galactosidase activity were determined weekly, and protein expression was determined after both $4 \mathrm{~h}$ (short term) and 12 consecutive weeks (long term) of exposure. The unexposed strain was used as the control.

\subsection{Bacterial Population Determination}

Each week, bacterial populations for both the aspirin-exposed cells and the control (without aspirin) were determined. In this procedure, the bacterial population was determined by plating both the control and aspirin-exposed cells onto MRS agar. The aspirin- exposed cell was prepared by centrifuging a cell that had already been exposed to aspirin for an average of $4 \mathrm{~h}$ daily for five days. The aspirin-exposed cell was then serially diluted in $9 \mathrm{ml}$ of sterile $0.1 \%$ peptone water, $100 \mu \mathrm{l}$ of appropriate dilutions were then surface plated onto MRS agar in triplicate and then incubated at $37^{\circ} \mathrm{C}$ for $48 \mathrm{~h}$. The population count for the control (without aspirin exposure) was determined using a similar procedure. Bacterial population was determined by counting colony forming units (CFU). Plates containing between 25 and 250 bacterial colonies were included in the analysis (Obanla \& Ibrahim, 2015).

\section{$2.5 \beta$-Galactosidase Activity Assay}

$\beta$-Galactosidase activity was determined using the method described by Ibrahim and O'sullivan (2000) with minor modifications. One hundred microliters of each sample were added to $900 \mu \mathrm{L}$ of $\mathrm{Z}$ buffer $(0.06 \mathrm{M}$ $\left.\mathrm{Na}_{2} \mathrm{HPO}_{4} ; 0.04 \mathrm{M} \mathrm{NaH}_{2} \mathrm{PO}_{4} ; 0.01 \mathrm{M} \mathrm{KCL} ; 0.001 \mathrm{M} \mathrm{MgSO}_{4} .7 \mathrm{H}_{2} \mathrm{O}\right)$. Next, ten microliters of chloroform were added to each sample and the solution was shaken for $30 \mathrm{~min}$ at $37^{\circ} \mathrm{C}$. Reactions were triggered by adding 200 $\mu \mathrm{l}$ of o-nitrophenyl- $\beta$-D-galactopyranoside substrate $(4 \mathrm{mg} / \mathrm{ml}$ in $0.1 \mathrm{M}$ phosphate buffer) to the samples. The 
temperature of samples was maintained at $37^{\circ} \mathrm{C}$ until a strong yellow color was produced, and the time was noted. The reaction was then stopped by adding $500 \mu 1$ of $1 \mathrm{M} \mathrm{Na}_{2} \mathrm{CO}_{3}$. Finally, optical density was measured at $420 \mathrm{~nm}$ and $550 \mathrm{~nm}$ for each sample. Miller units of $\beta$ - galactosidase ( $\beta$-gal) were calculated using the following equation:

$$
100\left[\mathrm{OD}_{(420 \mathrm{~nm})}-175 \times \mathrm{OD}_{(550 \mathrm{~nm})} /\left(\mathrm{T} \times \mathrm{V} \times \mathrm{OD}_{(600 \mathrm{~nm})}\right)\right],
$$

Where $\mathrm{T}=$ time and $\mathrm{V}=$ volume.

\subsection{Sodium Dodecyl Sulfate-Polyacrylamide Gel Electrophoresis (SDS-PAGE) Assay}

Total protein from $9 \mathrm{ml}$ of active sample of unexposed cells, $4 \mathrm{~h}$ aspirin- exposed cells (short term) and 12-week aspirin- exposed cells (long term) was extracted by centrifugation at $5000 \times \mathrm{g}$ for 10 minutes. Cells samples from each treatment groups were was homogenized separately by adding $4 \mathrm{ml}$ of B-PER ${ }^{\circledR}$ (B-PER ${ }^{\circledR}$ Bacterial Protein Extraction Reagent Thermo Scientific) per gram of cell pellet and then incubated at room temperature for $10 \mathrm{~min}$. Lysed cells were then centrifuged at $15,000 \times \mathrm{g}$ for $5 \mathrm{~min}$ to separate soluble proteins from insoluble ones. The total sample protein concentration was determined using the Pierce TM BCA assay kit (Rockford, IL). An appropriate volume of samples containing $20 \mu \mathrm{g}$ of total protein was solubilized in a sample buffer containing 3\% SDS and 5\% $\beta$-mercaptoethanol and boiled for $5 \mathrm{~min}$ to denature the protein. $17 \mu \mathrm{l}$ samples were loaded onto a $12 \%$ gel. Electrophoresis was performed at $200 \mathrm{~V}$ for approximately $60 \mathrm{~min}$. Proteins were visualized by Coomassie Blue staining $(0.1 \%$ Coomassie Blue, $10 \%$ acetic acid, $40 \%$ methanol). Proteins were visualized by Coomassie Blue staining ( $0.1 \%$ Coomassie Blue, $10 \%$ acetic acid, $40 \%$ methanol) on a BIORAD

\subsection{Experimental Design and Statistical Analysis}

The study was conducted using a completely randomized design with three replications. Treatments included a short term exposed strain, a long term exposed strain, and a long term exposed strain in the presence of $6 \mathrm{mg} / \mathrm{ml}$ aspirin. The differences among the treatments and with the control (wild strain) were compared using one way ANOVA (SAS version 9.2, SAS Institute, Cary, NC). Differences in means were considered significant when P $<$ 0.05 . The data were verified for normality before conducting the ANOVA test.

\section{Results}

Figure 1 shows the growth of both the unexposed strain and long term aspirin-exposed cells during incubation at $37^{\circ} \mathrm{C}$ for $9 \mathrm{~h}$. Both types of cells grew during the incubation period, and turbidity reached 0.9 within $9 \mathrm{~h}$. There was a similar pattern in the growth curves of both unexposed and long term exposed cells with no significant difference between the two types of cells. This suggests an overall improvement of growth and survival after long term exposure to aspirin. The improvement in the exposed strain could be due to rapid adaptation to the growth-inhibitory environment which favors the accumulation of multiple small steps mutations. Figure 2 shows a comparison of the effects of the addition of $6 \mathrm{mg} / \mathrm{ml}$ of aspirin on both the unexposed and exposed cells. The results indicated that there was no significant difference $(p>0.05)$ between the unexposed and exposed strain incubated with $6 \mathrm{mg} / \mathrm{ml}$ aspirin. The results also suggested that growth inhibition occurred when $6 \mathrm{mg} / \mathrm{ml} \mathrm{of}$ aspirin was incubated with unexposed cells during the first $4 \mathrm{~h}$ of incubation however, with the addition of 6 $\mathrm{mg} / \mathrm{ml}$ of aspirin to the exposed cell; no noticeable changes in growth were observed. The results also suggested that growth inhibition occurred when $6 \mathrm{mg} / \mathrm{ml}$ of aspirin was incubated with the unexposed cell during the first $4 \mathrm{~h}$ of incubation. Our results showed a similar trend with the exposed and unexposed strains with no significant difference $(\mathrm{P} \leq 0.05)$. This would suggest an overall improvement in the survival of aspirin exposed cells.

Figure 3 shows the weekly population count for both exposed and unexposed cells. There was an average weekly population count of approximately $8.8 \log \mathrm{CFU} / \mathrm{ml}$ for the unexposed cells. However, an approximately $4 \log$ reduction in the population was observed when unexposed cells were treated with $6 \mathrm{mg} / \mathrm{ml}$ aspirin, indicating a higher mortality rate for the aspirin-exposed strain during the first few weeks of exposure. There was a significant weekly improvement in the population count of the aspirin-exposed strain over time. There was no significant difference $(\mathrm{P}>0.05)$ between the population of the wild type and the aspirin-exposed strain after 9 weeks of sequential exposure to aspirin. The $\beta$-galactosidase activity between wild and exposed strains of $L$.rhamnosus was determined as shown in Table 1 . The unexposed strain of L. rhamnosus produced a significantly higher $\beta$-galactosidase activity of approximately $154.0 \pm 2.5(\mathrm{p}<0.01)$ compared to the aspirin-exposed strain. However; the $\beta$-galactosidase activity, which could be characterized as functionality, was completely inhibited in the aspirin-exposed strain regardless of the duration of exposure $(\mathrm{P}<0.01)$. The effects of aspirin on L. rhamnosus protein concentrations are shown in Figure 3. The results suggest that the total protein concentration measured in unexposed cells was $232.85 \mu \mathrm{g} / \mathrm{cell}$. When the strain was exposed to $6 \mathrm{mg} / \mathrm{mL}$ of aspirin for $4 \mathrm{~h}$, a significant decrease in protein concentration was observed $(137.72 \mu \mathrm{g} / \mathrm{cell})$. In contrast, the protein concentration increased 
significantly from $137.72 \mu \mathrm{g} / \mathrm{cell}$ in $4 \mathrm{~h}$ to $357.24 \mu \mathrm{g} / \mathrm{cell}$ after 12 weeks of sequential exposure to the same concentration of aspirin. This could be due to the acquisition of exogenous genes or as a result of mutation(s) in chromosomal genes that mediate resistance to aspirin.

Table 1. $\beta$-Gal activity of the wild and aspirin exposed strain

\begin{tabular}{ccc}
\hline Exposure in weeks & Wild $\beta$-Gal activity (miller units) & Aspirin exposed $\beta$-Gal \\
\hline 1 & $150 \pm 2.5$ & 0.00 \\
2 & $151 \pm 2.5$ & 0.00 \\
3 & $151 \pm 2.5$ & 0.00 \\
4 & $150 \pm 2.5$ & 0.00 \\
5 & $158 \pm 1.8$ & 0.00 \\
6 & $155 \pm 1.6$ & 0.00 \\
7 & $154 \pm 2.8$ & 0.00 \\
11 & $151 \pm 2.5$ & 0.00 \\
12 & $161 \pm 2.5$ & 0.00 \\
\hline
\end{tabular}

*Assays were done using permeabilized whole cells, and units of activity were calculated as described by Miller (1972).

$\mathrm{N}=3$

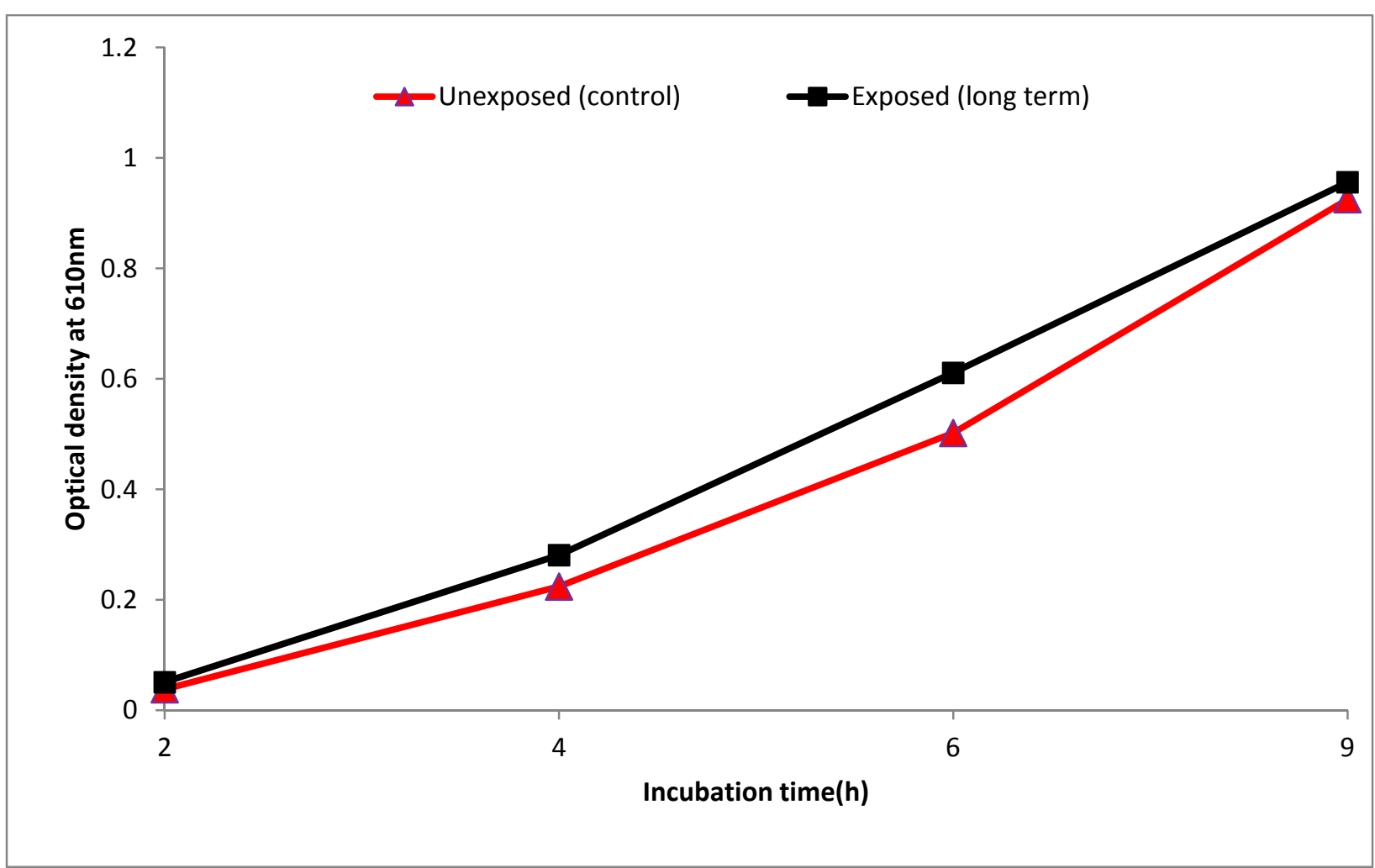

Figure 1. Growth of Lactobacillus rhamnosus in MRS for unxposed cells and long term aspirin exposed cells 


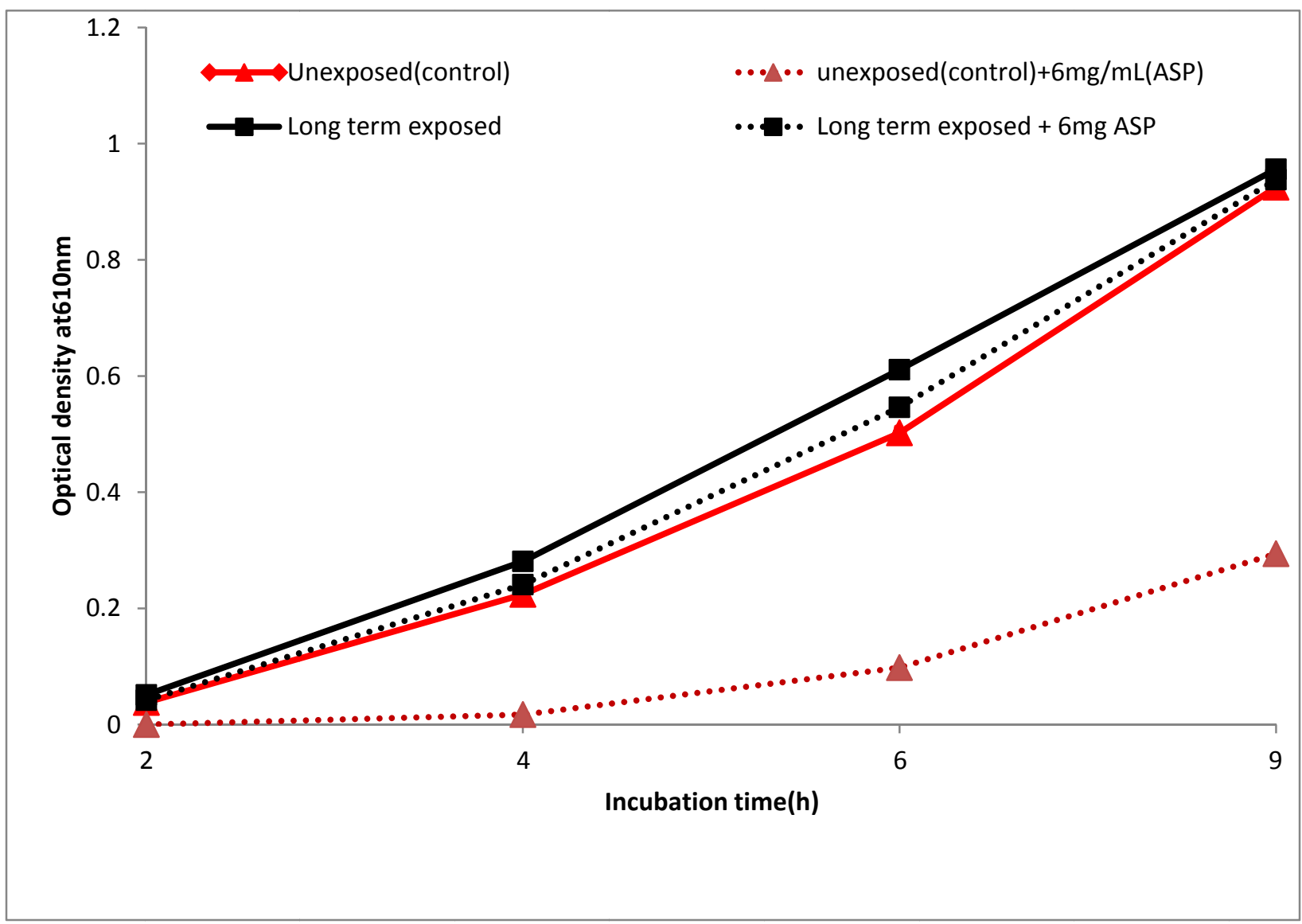

Figure 2. Growth of Lactobacillus rhamnosus for both unexposed (control) and long term exposed cells in MRS broth without or in the presences of $6 \mathrm{mg} / \mathrm{ml}$ asprin

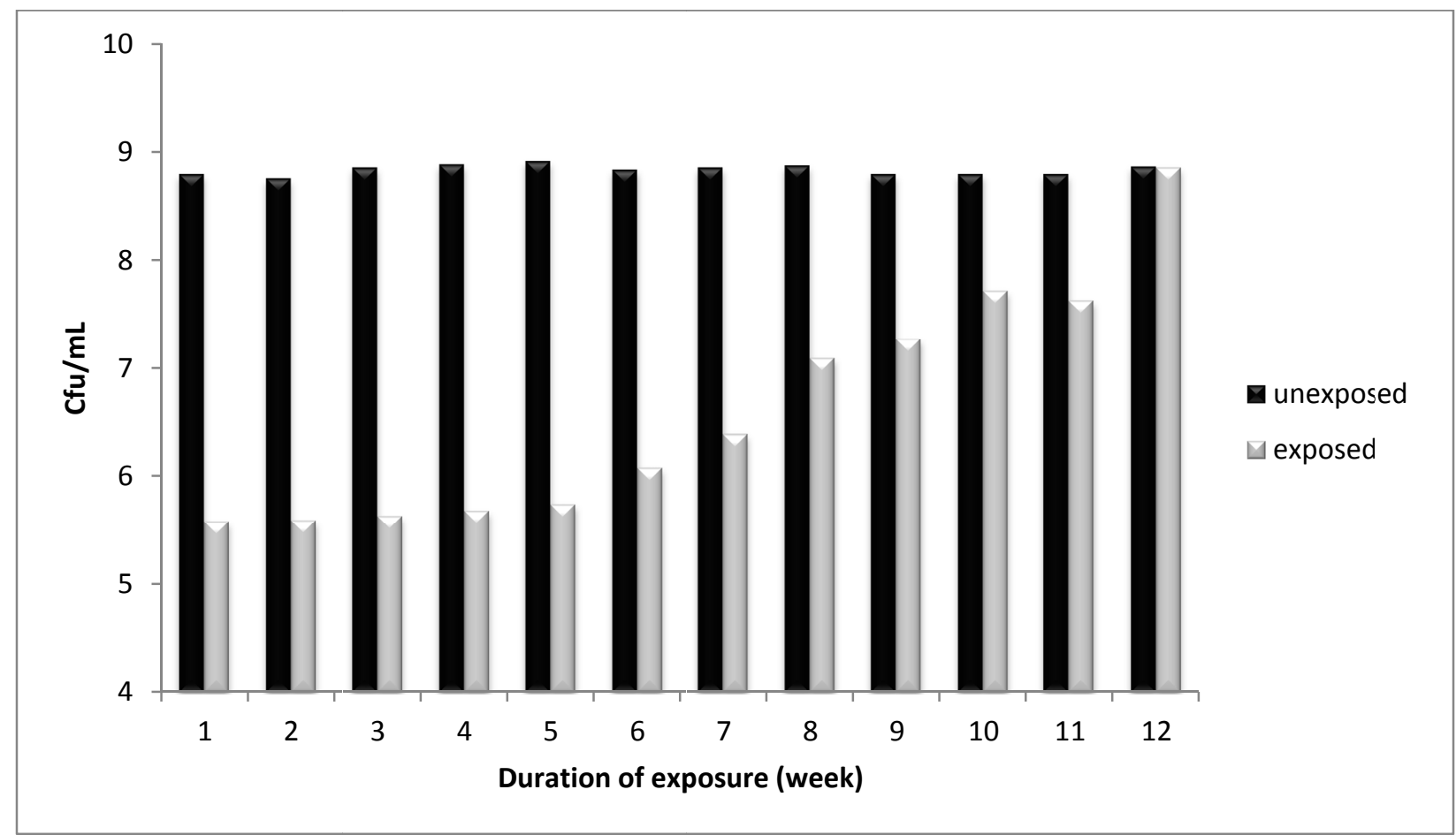

Figure 3. Population of unexposed L. rhamnosus and 4hours continous exposure to aspirin for 12 consecutive weeks 


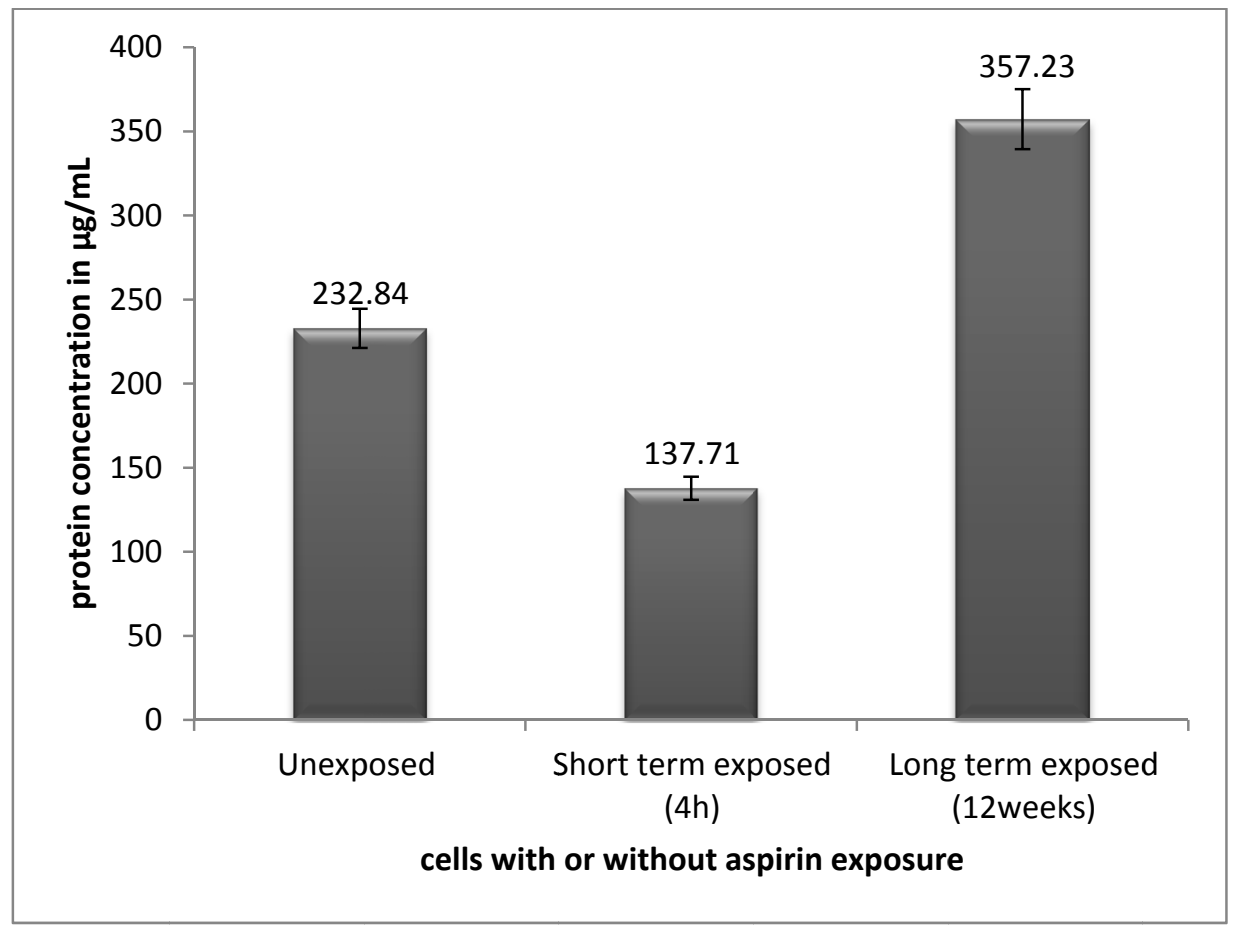

Figure 4. Protein concentration for both wild and exposed strain

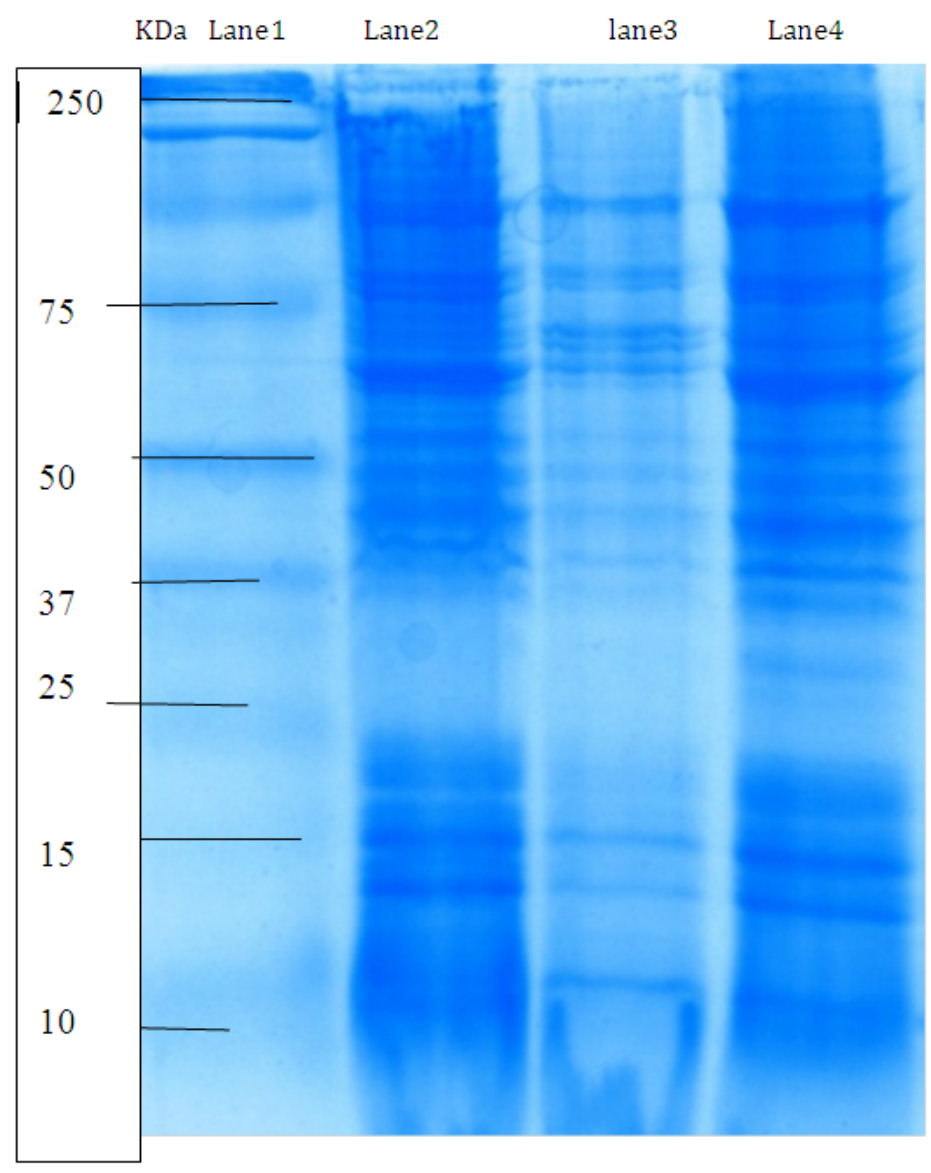

Figure 5. Coomassie blue Stained Sodium Dodecyl Sulfate Polyacrylamide Gel of Lactobacillus rhamnosus before and after exposure to aspirin: Lane 1- Fisher protein markers, Lane 2 unexposed type, Lane 3- 4 hour exposure to aspirin, Lane 4-long term exposure to aspirin 
The $12 \%$ SDS-PAGE of L. rhamnosus strain extracts for the individual treatment groups under the study generated Coomassie blue stained protein patterns consisting of about 15 distinct bands (Figure 5). The band components ranged in molecular weight from 12 to $250 \mathrm{kDA}$. Each of the treatment groups produced a characteristic band pattern identifiable by the position and intensity of the bands. Similarities and differences among the patterns with respect to the number and electrophoresis mobility of protein were observed. The overall protein band pattern identifies about 10 bands similarity among the different treatment groups; however, variation in the intensity of some bands was obvious. The band patterns exhibited in the wild strains were more similar to the band profile of those strains with long term exposure to aspirin. The electrophoresis pattern in the wild strains (no aspirin treatment),showed 11 or 12 protein bands ranging from $14 \mathrm{kDa}$ to $250 \mathrm{kDa}$, with 9 major bands.(14, 18, 25, 45,50, $52,60,75$, and $100 \mathrm{kDa}$ ). In contrast, $15-16$ proteins were observed in each of the L. rhamnosus strains following short or long term exposure to aspirin, with the presence or absence of some protein bands with a molecular weight of approximately $12,15,18,25,30,37,42,45,50,60,63,65,75,100$, and 110kDa. Although, shared band patterns were observed between the short-term and long-term aspirin treatment strains, much higher band intensity is prominent in the latter. Following 12 weeks of aspirin treatment, the L. rhamnosus strains exhibited unique protein bands of between $37-25 \mathrm{kDA}$ in size. Further characterization of the specific polypeptides in that region is warranted to enhance our understanding of the role of aspirin over the long term.

\section{Discussion}

Low dose aspirin (ASA) has been associated with a wide range of adverse side effects in the upper gastrointestinal (GI) tract, which range from troublesome symptoms without mucosal lesions to more serious toxicity, including ulcers, GI bleeding, perforation and even death (Sostres \& Gargallo, 2012). In addition, there has been an increase in regular intake of aspirin which had been reported to have adverse effects on bacterial growth and functionality (Thiagarajan \& Jankowski, 2012). Salicylate, the active ingredient in aspirin, has been shown to induce a number of distinct morphological and physiological changes in bacteria. This is especially true when bacteria are grown in the presence of sub inhibitory concentrations of salicylate over time (Price, Lee, \& Gustafson, 2000). Bacterial antibiotic resistance arises due to the acquisition of exogenous genes or as a result of mutation(s) in chromosomal genes that mediate resistance to one or a number of closely related antibiotics (Price et al., 2000). Growth of several bacterial species in the presence of salicylate leads to an increase in the species' levels of intrinsic antibiotic resistance (Price et al., 2000). Increased resistance to antibiotics in the presence of salicylate has been attributed to the alteration in membrane-associated proteins such as prions and transporters, leading to a reduction in drug accumulation (Price et al., 2000). It has also been reported by Purdom and Anderson (2009) that mutant bacteria may develop new genes which may improve survival but affect phenotypic characteristics. Aspirin is an acetylating agent in which the acetyl group covalently attaches to a serine residue (S530) at the active site of the cyclooxygenase- 1 enzyme and irreversibly inhibits the production of prostogalands (Tótha, Muszbeka, \& Komáromi, 2013). Our study suggests that gut flora that is regularly exposed to a particular aspirin dosage could develop a mechanism that helps the gut flora to survive when exposed to aspirin over a long period of time. However, the functionality of gut flora may change. Individuals who are on common medications could maintain gut flora functionality by consuming probiotics. Probiotics could thus help maintain and contribute to human health by improving the immune system against gastrointestinal infections and other diseases especially among the elderly population

\section{Conclusion}

In this study, we examined the long term exposure effects of aspirin on functionality and growth of $L$. rhamnosus. We found a significant improvement in the survival and growth of $L$. rhamnosus during long term exposure to aspirin; however, $\beta$-gal activity was completely inhibited. Although the mechanism by which aspirin inhibits the $\beta$-gal activity of $L$. rhamnosus was not investigated in this study, it would appear that aspirin can inhibit enzymatic activities irreversibly. It could thus be concluded that L. rhamnosus survival and growth rate improved on a long term exposure to a sub inhibitory concentration of aspirin. However, due to the inhibition of $\beta$-gal activity, it is important to consume more probiotics when taking medical drugs such as aspirin in order to improve functionality of probiotics and thereby enhancing aspirin's health benefits. Further studies are needed to ascertain the mechanism of $\beta$-gal inhibition on exposure of L. rhamnosus to aspirin.

\section{References}

Alazzeh, A. Y., Ibrahim, S. A., Song, D., Shahbazi, A., \& AbuGhazaleh, A. A. (2009). Carbohydrate and protein sources influence the induction of $\alpha$-and $\beta$-galactosidases in Lactobacillus reuteri. Food Chemistry, 117(4), 654-659.http://dx.doi.org/10.1016/j.foodchem.2009.04.065

Aumercier, M., Murray, D. M., \& Rosner, J. L. (1990). Potentiation of susceptibility to aminoglycosides by 
salicylate in Escherichia coli. Antimicrob Agent Chemother, 34, $786-91$. http://dx.doi.org/10.1128/AAC.34.5.786

Biagi, E., Candela, M., Turroni, S., Garagnani, P., Franceschi, C., \&Brigidi, P. (2012). Ageing and gut microbes: Perspectives for health maintenance and longevity. Pharmacological Research: The Official Journal of the Italian Pharmacological Association, 69(1), 11-20. http://dx.doi.org/10.1016/j.phrs.2012.10.005

Brestoff, J. R., \& Artis, D. (2013). Commensal bacteria at the interface of host metabolism and the immune system. Nature Immunology, 14(7), 676-684.

Cederlund, H., \& Mardh, P. A. (1993). Antibacterial activities of non-antibiotic drugs. J. Antimicrob. Chemother, $32,355-65$.

Gill, H. S. (2003). Probiotics to enhance anti-infective defences in the gastrointestinal tract. Best Practice \& Research Clinical Gastroenterology, 17(5), 755-773.

Gill, H. S., Rutherfurd, K. J., \& Cross, M. L. (2001). Dietary probiotic supplementation enhances natural killer cell activity in the elderly: An investigation of age-related immunological changes. Journal of Clinical Immunology, 21(4), 264-271.

Gustafsson, I., Sjolund, M., Torell, E., Johannesson, M., Engstrand, L., Cars, O., \& Andersson, D. I. (2003). Bacteria with increased mutation frequency and antibiotic resistance are enriched in the commensal flora of patients with high antibiotic usage. J AntimicrobChemother, 52, 645-650.

Harari, D., Gurwitz, J. H., Avorn, J., Bohn, R., \&Minaker, K. L. (1996). Bowel habit in relation to age and gender: findings from the National Health Interview Survey and clinical implications. Archives of internal medicine, 156(3), 315-320.

Hayek, S. A., Shahbazi, A., Worku, M., \& Ibrahim, S. A. (2013). Enzymatic activity of Lactobacillus grown in a sweet potato base medium. British Microbiology Research Journal, 4(5), 509-522.

Hennekens, C. H., \& Schneider, W. R. (2008). The need for wider and appropriate utilization of aspirin and statins in the treatment and prevention of cardiovascular disease. Expert Rev CardiovascTher, 6(1), 95-107.

Huang, E. S., Strate, L. L., Ho, W. W., Lee, S. S., \& Chan, A. T. (2010). A prospective study of aspirin use and the risk of gastrointestinal bleeding in men. PLoS One, 5(12), e15721. http://dx.doi.org/10.1371/journal.pone.0015721

Ibrahim, S. A., Alazzeh, A. Y., Awaisheh, S. S., Song, D., Shahbazi, A., \& AbuGhazaleh, A. A. (2010). Enhancement of $\alpha$-and $\beta$-galactosidase activity in Lactobacillus reuteri by different metal ions. Biological Trace Element Research, 136(1), 106-116.

Ibrahim, S. A., \& O’Sullivan, D. J. (2000). Use of chemical mutagenesis for the isolation of food grade $\beta$-Galactosidase overproducing mutants of Bifidobacteria, Lactobacilli and Streptococcus thermophilus. Journal of Dairy Science, 83(5), 923-930.

Moubareck, C., Gavini, F., Vaugien, L., Butel, M. J., \& Doucet-Populaire, F. (2005). Antimicrobial susceptibility of bifidobacteria. Journal of Antimicrobial Chemotherapy, 55, 38-44.

Obanla, T. O. (2014). The impact of commonly administered medications on viability and functionality of bifidobacteria (Order No. 1557890). ProQuest Dissertations \& Theses Full Text. (1550385146). Retrieved from http://search.proquest.com/docview/1550385146? accountid=12711

Obanla, T., \& Ibrahim, S. A. (2015). Survival and Growth of Lactobacillus Rhamnosus (ATCC 53103) in the Presence of Aspirin. J Nutr Health Food Eng., 2(6), 00076.http://dx.doi.org/10.15406/jnhfe.2015.02.00076

Ouwehand, A. C., Salminen, S., \& Isolauri, E. (2002). Probiotics: An overview of beneficial effects. Antonie Van Leeuwenhoek, 82(1-4), 279-289. http://dx.doi.org/10.1023/A:1020620607611

Song, D., Ibrahim, S., \& Hayek, S. (2012). Recent application of probiotics in food and agricultural science. In E. C. Rigobelo (Ed.), Probiotics (pp. 3-36). InTech.http://dx.doi.org/10.5772/50121

Upreti, R. K., Kannan, A., \& Pant, A. B. (2010).Experimental impact of aspirin exposure on rat intestinal bacteria, epithelial cells and cell line. Human \& experimental toxicology. http://dx.doi.org/10.1177/0960327110363333

Wall, T. (2005). Environmental interactions of Lactobacillus reuteri (Vol. 2005, No. 104).

Woodmansey, E. J. (2007). Intestinal bacteria and ageing. Journal of Applied Microbiology, 102(5), $1178-1186$. http://dx.doi.org/10.1111/j.1365-2672.2007.03400.x 
Woodmansey, E. J., McMurdo, M. E., Macfarlane, G. T., \& Macfarlane, S. (2004). Comparison of compositions and metabolic activities of fecal microbiotas in young adults and in antibiotic-treated and non-antibiotic-treated elderly subjects. Applied and Environmental Microbiology, 70(10), 6113-6122. http://dx.doi.org/10.1128/AEM.70.10.6113-6122.2004

\section{Copyrights}

Copyright for this article is retained by the author(s), with first publication rights granted to the journal.

This is an open-access article distributed under the terms and conditions of the CreativeCommons Attribution license (http://creativecommons.org/licenses/by/3.0/). 